\title{
JUDICIAL POWERS OF INTERPRETATION UNDER FOREIGN CODES.
}

The Swiss Civil Code, ${ }^{1}$ the most modern of European codes, contains in Article One of its "Introductory Title" an unusual provision evidencing a changed attitude towards a political dogma of the nineteenth century, the separation of the legislatíve and judicial functions. It reads:

"Art. $x$. The written law governs all matters to which either the letter or spirit of any of its provisions refer. In the absence of a provision of such law applicable to a case, the judge shall decide according to customary law and, in the absence of custom, according to the rule which he would establish were he acting as legislator.

"He shall base his decisions upon the solutions adopted by text-writers and in judicial decisions."

This is the most radical statement of its kind in any foreign code known to the writer. It is proposed here to examine a few of the leading codes of Europe and South America, to trace, if possible, the direction which the development of this subject is taking.

Before examining the codes it may be well to state the problem which interpretation presents to the civilian jurist and which different codes have regulated in different ways.

Codification presents the danger of arresting legal progress. We are all ready to admit that law, as a manifestation of society, is like a flowing stream, that struggles to keep abreast of social development. When law is crystallized into the unvarying text of a code, the flow of its expression is checked, though social progress continues its course. Upon interpretation or upon periodic revision must depend the maintenance of harmony between the injunctions of the code and the practice of every-day life. Now, periodic revision of the codes has not been the

2 Adopted December 10 , igo7 (in effect January 1, 1912).

- The Swiss Civil Code has been translated by Robert P. Shick for the Comparative Law Bureau of the American Bar Association (Boston Book Company, Boston, 1915). The writer has preferred to use his own translation. 
practice of any of the countries it is proposed to study here. Of cuurse subsequent legislation has renovated parts or added rules to govern new institutions. But upon interpretation has chiefly fallen the task of maintaining parallelism between the codes and social requirements.

Where a code enjoys, substantially unaltered, a life long enough to span more or less profound changes in social and economic ideals, there grows up necessarily a body of extra-legislative rules, supplementing the code, often in contradiction to its precepts, and representing the forward movement of society since the adoption of the code. As the code grows more antiquated, interpretation becomes bolder, until parts of the code become a dead letter. The praetorian law of Rome gradually upplemented and corrected the jus civile of the old type; in the Anglo-American system we have a dual system of common law and equity, equity being a correction of a system which changed and still changes too slowly; while the last century has given rise, in the countries of codification, to a system of authority parallel to the codes, interpretative of and complementary to them, and of increasing importance. This body of authority is composed of decisions of the court, or, in continental terminology, "jurisprudence."

\section{I.}

In France, before the Revolution, the courts, known as Parliaments, used to issue regulative decrees, ${ }^{5}$ subject to royal approval, which served not only as decisions in the specific instances but aiso remedied deficiencies of the law in future application. The Parliaments were exercising a legislative function. The Revolution, with its new philosophy of the State, changed

"The Spanish Civil Code in Art. I of its "Additional Provisions" provides machinery for perodic revision. Each year the Supreme Court should transmit to the Minister of Justice a report upon the defects and insuftciencies noted in the law and the Minister of Justice should transmit the same to the permanent codification commission. This machinery has never been used. The Chilean Civil Code, Art. 5 , provides that the Supreme Court shall make a similar report to the President of the Republic. This has never been followed out.

"Lambert: “La Fonction du Droit Civil Comparé" (Paris, 1903), pp. 173-208.

"Arrêts de règlement" 
all that. Judges and legislators had, henceforth, to keep strictly within the sphere of their proper powers.

The French Civil Code, enacted in 1804 , with its history of more than a century, spans the industrial revolution and many important social reforms. It has been altered and expanded, while a great mass of interpretation has accumulated about it.

The Code contains two Articles bearing directly on the question of application and interpretation.

"Art. 4. The judge who refuses to render judgment, under pretext of the silence, obscurity or insufficiency of the law, may be prosecuted as guilty of denial of justice.

"Art. 5. Judges may not, in the cases brought before them, render judgment in the form of gencral or regulative decrees."

Silence or defect of the law does not excuse the judge from pronouncing a decision. If he finds no solution in the Code or statutes, he seeks enlightenment in analogy, the general spirit of the law, custom, judicial decisions, the literature of the law, known as "doctrine," and his own natural sense of equity. The codifiers realized that no code could presume to regulate in. anticipation every possible combination of facts. But they also realized that justice must be dispensed by the courts and only by the courts. The legislature could not be called upon to express its will in isolated judicial contests, nor could the opinions of the judges be given effect beyond the specific set of facts which called them forth, for each of these alternatives, it was believed, would confuse political functions.

Thus, there has gradually accumulated about the Conde a mass of decisions both interpretative and creative. To the common law lawyer, it does not seem stretching the principle of res judicata to regard a single decision as binding courts upon similar sets of fact. Sir Frederick Pollock pointed out that to do so is merely applying to case-law the scientific principle that uniform consequences flow from uniform facts. ${ }^{\circ}$ It is thus made possible, in a system of judge-made law, to predict the

"Essays in Jurisprudence and Ethics" (London, I882), Chap. 9 
decision of the court upon a given set of facts. But it is very evident from Article Five of the Civil Code that the French jurist regards such a respect for the single case as an unlawful extension of julicial power. For a court, by its opinion in the case of $A$. v. $B$., to bind for future time all other courts upon a similar state of facts, would be to "render judgment in the form of general or regulative decrees."

There is one exception in the French system, whereby a decision of a higher court is made binding upon a lower court. The Sipreme Court of France may not render final judgment upon the facts of a case, but only declare wherein a lower tribunal has erred. Cases which go up to the Supreme Court do not receive final judgment there except when affirmed. If the court below is found to have erred, the case is sent back for rejudgment by another lower court. As illustrating how contrary to the feeling of the French jurist was the idea of binding one court by proceedings before another, we find that after a lower court has been declared in error and the case has been remanded to other judges, these are still free, at least once, to disagree with the Supreme Court. The case then goes to the Supreme Court a second time, where it is studied in plenary session. If the lower court is again convicted of error, the case is returned and this time, the lower court must abide by the conclusions of law of its superior. However, it is bound only in the specific case. No other court is bound, and the same court may in theory return to its original opinion in a new case presenting the same facts.?

What value, then, has "jurisprudence" under such a system? It is not law in the sense that it has any sanctioned authority. Its sole authority is that of reason. In the AngloAmerican system a single decision of a higher court establishes a binding precedent upon lower courts. In France each court has its own "jurisprudence," that is to say, a line of its own decisions, which by their continuity establishes its doctrines upon a given point. It is usual to speak of the "jurisprudence" of 312-319.

'Law April I, I837. Cf. Faye, "Cour du Cassation" (Paris, I903), pp. 
the "Cour de Cassation," of the "Cour d'Appel," or of the "Tribunal d'Aix." There is a great likelihood, because of the natural conservatism and dignity of courts, that a rule that has grown up through a current of decisions, will persist, that is to say, be followed by the particular court in future cases. Of course the "jurisprudence" of the Supreme Court has greater weight than that of the lower courts. And yet, until an extralegislative doctrine has been adhéred to for a period by all courts, it cannot be said to be established as a predictable ruling over the whole country. We might say that, after a period of time, out of the unhampered conflict between courts, there gradually distills certain more or less well defined streams of judicial doctrine. These are to be obtained from the collections of French "jurisprudence." While they have not the weight of decisions under the common law system, they have such importance that they must be consulted in connection with the Code in every case.

Along side of "jurisprudence" as a source of interpretation is "doctrine," a term regularly used correlatively with "jurisprudence" and meaning the theories developed by textwriters. In France "doctrine" had a greater historical importance than "jurisprudence." But this is no longer true. After the adoption of the Civil Code, authors devoted their efforts to interpretations of the texts of the Code, not in the light of changing social requirements but of a rigorous logic. The consequence was that the great commentaries of the Civil Code were not so much critical legal studies as repositories of toryism. The time came when the courts were forced to break away from this early spirit of interpretation and to commence the more constructive period of interpretation through "jurisprudence," . which is in the flush of its success today. ${ }^{8}$

II.

Let us now examine the law of some countries where French influence has been great.

The Italian Civil Code (1865) declares:

'Cf. Lambert, "Fonction du Droit Civil Comparé," pp. 15-22.

- Art. 3, Sec. 2. 
"Whenever a question cannot be settled by specific statutory rules, regard shall be had to provisions regulating analogous cașes or analogous subjects; when the question still remains in doubt, a decision shall be rendered according to the general principles of the law."

The Civil Code of Procedure ${ }^{10}$ subjects the judge who refuses to decide a case, properly brought before him, to a civil penalty.

The "general principles" of the law are the juridical spirit of the code, together with "jurisprudence" and "doctrine" as we have described them. In Italy the decided case enjoys no greater authority than in France. ${ }^{11}$ Non exemplis, sed legibus iudicandum.

In the Spanish Civil Code (1889) ${ }^{12}$ is an echo of the principles just stated.

"The court refusing to render judgment under pretext of the silence, obscurity or insufficiency of the law renders itself liable thereby.

"When there is no law precisely applicable to the point in controversy, the custom of the place shall be applied, and in the absence of a custom the general principles of the law."1s

In Spain the only "jurisprudence" of importance is that of the Supreme Court and the opinions of this court are the only ones that receive faithful publication.

" Art. 782, Sec. 2.

"I "Instituzioni di Diritto Civile Italiano," Emanuele Gianturco (7th Ed. 1905, Florence), p. I9.

Art. 6.

${ }^{2}$ The very early law of Spain was not like Art. 6 of the present Code, as shown by the ancient Sictc Partidas, Part 7, Title 22, Law II, ". . when judges are in doubt in what manner they shall give their judgments in view of the evidence and of the rights which both the parties prove before them, they shall make inquiry of wise men of those places where they are sitting in judgment, who shall be free of all suspicion, and shall make plain to them all the facts as it was done before them. And if by the response of these wise men the judges are able to dissipate the doubt in which they stood, they shall render judgment in the manner which we have already shown. But if certain of them cannot dissipate that doubt, they shall have all the proceedings drawn up in writing, just as it transpired before them, well and truthfully, and afterwards have it read to the parties in order that these may see and understand whether all has been written that was argued. And if the judges find that anything has beeen added, omitted or changed, they shall rectify it, and afterwards seal the writing with their seals and give to each one of the parties his own written record and they shall bear them to the 
III.

In the Spanish-American Republics, Spanish and French infucence has been strong. It is remarkable low closely these new-world countries, less bound by tradition and the civilian point of view, have followed the continental doctrine.

The Chilean Civil Code of 1885 is a very complete codo and a remarkable piece of legislation. Let us examine two Articles from its "Introductory Title":

"Art. 3. To the legislator alone it falls to explain or interpret the law in a manner universally obligatory."

This is, we may say, the other side of the doctrine of the French Code, which declares that "judges may not render judgment in the form of general or regulative decrees." This should have scemed adequate to fix the status of "jurisprudence," but the Chilean codifier continued in the same Article:

"Judicial decisions have no binding force save in the causes in which they are actually pronounced."

Later, having laid down certain principles to govern interpretation, the Code continues: -

"Art. 24. In cases in which the preceding rules of interpretation cannot be applied, obscure or contradictory passages (of the law) shall be interpreted in the manner most conformable to the general spirit of legislative law and natural equity."

In the Argentine Republic the Civil Code ( 1869 ) laid down the same strict rule of interpretation.

"Art. 16. If a question of civil law cannot be decided either by the words themselves or by the spirit of the law, respect shall be

king. And after all this the judges shall inscribe a letter and send it to the king, explaining the whole matter and the doubt in which they stood. And thereupon the king, having the truth, may give judgment, or, if he so desires, send instruction to those judges as to how they shall render it. But no judge may do this to excuse-himself from work, or by reason of the length of the case, or for the fear, or love, or hate he may bear any of the parties; but only because he does not know how to choose the right, which he would like to, and ought to; for if he do otherwise, he shall, for that reason, receive punishment in the measure that the king holds him deserving of it." The Sicte Partidas werc one of the most famous codes of the Middle Ages, compiled in the middle of the thirtcenth century by Alfonso $X$ and deriving its name from the fact that it was divided into "seven parts." 
hald for the principles of analogous laws; and if the matter is then doubtful, the general principles of law shall be applied, with due consideration for the circumstances of the particular case."

An eminent Argentine commentator ${ }^{14}$ notes with regard to this article:

"The nistake is very generally made of believing that one or several harmonious decisions of the courts constitute "jurisprudence.' This error has led our courts to aim to deprive judges of their free power to interpret the law and apply it. To seek harmony and unifornity of decisions is to paralyze the evolution of law. There is no doubt but that the decisions of the courts of a nation deserve great respect; but they should not be considered as a higher rule hampering the judge and to be imposed upon other courts. It falls properly within the judge's sphere of liberty to interpret a law, and we should determine the weight to be given his interpretation by the uniformity observed in the manner of accepting it. Consequently the 'jurisprudence' of the courts, to possess force, requires the elements of time; of submission to a changing judiciary, of similarity of facts, and of frequency of application.

"The courts, high as they may be, may not bind the future, and assume to settle by their decisions the rules according to which succeeding cases are to be adjusted. That would be a presumption of infallibility. Thus, we regard the decisions of the court as elements of interpretation to be applied with the greatest prudence, and only when there is uniformity over a more or less long space of time, permitting a change of judiciary. They should be considered as an element of interpretation similar to "doctrine."

IV.

A Civil Code for the entire Empire came into force in Germany in 1900 . It had been in preparation twenty-six years and it is not surprising that the painstaking spirit of this nation produced a work recognized today as the most scientific codifcation of civil law.

This Code intentionally omitted all reference to the method of its interpretation. We find, in the form finally adopted by the legislature, no "introductory title" concerning the application and interpretation of laws, a part generally met in other

"Machado: "Exposición y Comentario del Código Civil Argentino" ' Luenos Aires, 1898), Vol. T, p. 50, note. 
colles. Why was it that so important a question as that of interpretation, which must necessarily affect the course of future legal derelupnent, should be left open to discussion?

The First Commission prepared a "project" or draft, the first Article of which commanded that the Code be interpreted by principles of analogy. Legal relations left unregulated by the Code were to be governed by rules to be gathered from analogous institutions of the Code; and if these were wanting, the principles underlying the spirit of the law as a whole were to be applied. In other words the Code was to be its own and sole source of interpretation. There was to be no recourse to a conmon law anterior to codification (Pandektcnrecht), or to Roman law or to "natural law." While requiring the judge to act even where the Code was silent, it took from him the freer exercise of conscience and intellect which we found characterized the French and other systems.

This provision disappeared in the second draft. The Second Commission realized the narrowness of the restriction. But no other was substituted.

What are, then, the sources of interpretation? The omission of the first Article from the first "project" was due to unwillingness to inject into the Code a controverted principle regarding the use of analogy in interpretation. There was doubt whether it could be called analogy at all to apply to legal relations originating after the Code, principles created for other institutions included within the Code; or whether for the judge to regulate such new institutions could be held to be interpretation at all.

In suppressing the Article the Second Commission registered its unwillingness to impose any positive regulation upon interpretation. It did not expressly adopt the view that principles regulating older institutions could be extended by analogy to regulate new and different ones; nor did it sanction the use of outside sources. But, at least, the failure of the Commission affirmatively to admit that the judge may draw from outside sources was as significant on the one hand as its suppression 
of the narrower regulation of interpretation by analogy on the other. The question of interpretation has been left open to debate. $^{15}$

\section{V.}

We should now be in a better position to appreciate the changed attitude of the Swiss legislator toward interpretation. IVe cannot do better than to turn to the "Exposé des motifs" of Dr. Eugen Hüber, drafter of the Swiss Code, to learn the legislative intent of Article One. He says: ${ }^{16}$

"A body of codified law is complete only in the sense that it may extend to the whole body of written law, but not in the sense that it should exclude every other source of law. When it is claimed, on the authority of antiquated theories, that codification creates a complete system of law and embraces, within its letter and spirit, the provisions necessary for all-cases, codification is confused with law in general. In our opinion law is one and entire; no judge may refuse to render a decision under pretext that the law is wanting. Nevertheless codification may very well present omissions; indeed, it ordinarily evidences numerous such. And how may we not then recognize that alongside of the codified law there may, and indeed must, exist other sources of law destined at need to supplement codified law?

"The written law should certainly be applied first. And it should be applied not only so far as its text permits, but also so far as any interpretation can stretch its spirit. Such is the sense of the first paragraph of Article One. But when written law is lacking, it is not possible, under the legislative sovereignty of the State, that is to say, under the written law, to deny recognition to a source of law which is being effectively observed. When legislation has not in! fact excluded such law by the establishment of specific rules, it would be inconsistent with itself to deny all value to it. It could not, indeed, so regard it, unless it replaced such law, which was in fact observed, by statutory law.

"To give expression to this, which is required by the very nature of things, the Code declares that in the absence of a text applicable to the case, the judge shall pronounce according to the customary law (Art. I, paragraph 2). . .

${ }^{25} \mathrm{C}$. Salleilles, "Introduction à l'Etude du droit Civil Allemand" (Paris, 1904), pp. 88-104.

s6 "Exposé des motifs de lavant projet" (Berne, 1901), p. 30. 
"Another case may present itself. There may be no customary law to fill the gap in the written law. Where then will the judge find the norm according to which he may render his decision? His own consciousness of what is legal must direct him. Nevertheless, it is not proper that he should form his convictions arbitrarily. He is obliged to enlighten his conscience by a scrious method worthy of the nature of his functions. In the first place he must seek what, under like facts, others have held or said. In this examination he shall proceed with all the care which is demanded of him by his office. He shall have regard to 'doctrine' and 'jurisprudence,' as is provided in paragraph Two of Article One. But if he finds there no indications he can follow out his own convictions, and the cnly direction which the law can then furnish him is that he should not decide arbitrarily, under the influence of accidental circumstances, such as pity. indignation or personal hatred, but as though, as legislator, he were pronouncing a rule to be applied afterwards to the facts acttially before him. This is the sense of the last paragraph of Article One. ${ }^{17}$

"It has the same meaning as the maxim of legal writers: 'In such cases the judge shall pronounce as would the wise lawmaker, had he anticipated the case." "

We may feel certain that Article One of the Swiss Code does not intend, by the use of the term "legislator," that the court shall have the power to render judgment in the form of "general or regulative decrees" universally applicable to future states of fact, such as was denied by Article Five of the French Civil Code. Nor does the reference to "doctrine" and "jurisprudence" in the last paragraph mean that the English system of case-law has been introduced into Switzerland. And yet it does indicate a marked change in the conception of the judicial function before an omission of the law.

The French Code, just a century old when the Swiss draft was submitted to the Federal Assembly, ${ }^{18}$ had aimed to sever the judicial from the legislative function while obligating the judge to act even in the silence of the law. The commentators, embued with the philosophy of the Revolution, strove to make

\footnotetext{
"In the preliminary draft the arrangement of Article One was different. Paragraph two required that in the ahsence of a customary rule, the judge should decide according to "doctrine" and "jurisprudence," while the last paragraph stated that in the absence of these sources he should act as legislator.

"May 28, 1904.
} 
the Code its own interpreter, using analogy and logic as their tools. To recognize authority in former judicial opinions was contrary to the spirit and even the words of Article Five. Consequently expressions of writers enjoyed a higher vogue than the opjinions of judges; and such continued to be the case until the courts, realizing the growing abyss between written and practised law, broke away from "doctrine" and commenced the modern evolution of French law, found largely in "jurisprudence." Of course "doctrine" was discredited and the authority of the courts rose in proportion.

We have scen how the other Latin codes followed in the path of the French Code, even in the young Latin-American countries. In Germany the question has been left for the courts and writers to determine. And yet, we may judge from the particularistic, as opposed to the doctrinal, spirit of this Code; from the refusal of the Commission to recognize specifically any source of interpretation untside the Code itself; from the experience of France in the years following the adoption of her Code; we may, I think, safely conclude that, for a period at least, the history of interpretation in Germany will be different from that in Switzerland.

If the Swiss judge is frankly directed to draw from sources outside the Code when the Code and customs are silent; and if he is directed to seck enlightenment from the body of judicial decisions, is it possible that there shall not grow up, parallel to the Code, a body of sanctioned law, consisting of judicial custom, similar indeed, within its own sphere, to Anglo-American judge-made law, with the reservation that respect shall be paid to a current of authority rather than to the single decision?

Layton B. Register.

Laze School, University of Pennsylvania. 